\title{
Bir Konjenital Miyotoni Olgusu ve Aile Taraması Anestezi ve Konjenital Miyotoni
}

\author{
A Case Of Myotonia Congenita and Family İnvestigation \\ Anesthesia and Myotonia Congenita \\ Suna SARIKAYA', Tahir Kurtuluş YOLDAŞ², Ece ÜNLÜ3 ${ }^{3}$ Sibel TAMER ${ }^{2}$ \\ 'Sivas Numune Hastanesi, Nöroloji Kliniği, Sivas \\ ${ }^{2}$ Ankara Dışkapı Yıldırım Beyazıt Eğitim ve Araştırma Hastanesi, Nöroloji Kliniği, Ankara \\ ${ }^{3}$ Ankara Dışkapı Yıldırım Beyazıt Eğitim ve Araştırma Hastanesi, FTR Kliniği, Ankara
}

\begin{abstract}
öz
Konjenital miyotoni, yaygın kas hipertrofisi, ilerleyici olmayan ağrısız miyotoni, ani kas kasılması sonrası gevşemekte güçlük ile karakterize, iskelet kasının nadir görülen kalıtsal bir hastalı̆ıdır. 54 yaşında, çocukluk döneminde hafif olan, geçirdiği tiroidektomi operasyonu sonrası belirginleşen, yaygın kas güçsüzlüğü ve katılığı olan kadın hastanın; erkek kardeşi, kız kardeşi ve 3 yeğenin de benzer şikayetleri vardı. Laboratuar çalışmalarında kreatin kinaz, elektrolitler ve tiroid fonksiyon testleri normaldi. İğne EMG (elektromiyografi) çalışmasında miyotonik deşarjlar saptandı. Sonuç olarak bazı miyotoni hastaları subkliniktir ve kas semptomları fark edilemeyebilir. Hastalara kas hastalıklarına yönelik iyi bir preoperativ anamnez ve aile öyküsü taraması önemlidir.
\end{abstract}

Anahtar Kelimeler: Thomsen hastalığı; miyotonik hastalıklar; kas güçsüzlüğü.

\begin{abstract}
Myotonia congenita is a rare hereditary disease of skeletal muscle, characterized by generalized muscle hypertrophy, non-progressive painless myotonia, and difficulty in relaxation after contraction. A 54 year- old female patient presented with generalized muscle stiffness and weakness after thyroidectomy operation. These problems were existed but mild in childhood. Her brother, sister and three nephews had similar complaints in the family. Needle EMG revealed myotonic discharges. Some myotonia patients may have subclinical muscular symptoms. A careful preoperative history of muscular symptoms and family history are important.
\end{abstract}

Keywords: Thomsen's disease; myotonic disorders; muscular weakness 


\section{GíRiş}

Bu yazıda anestezi sonrası güçsüzlük nedeniyle Konjenital miyotoni tanısı alan ve aile taraması sırasında 5 kişiye daha Konjenital miyotoni tanısı konulan bir olgu serisi sunuldu. Konjenital miyotoni çocukluk döneminde hafif bulgularla seyretmesi nedeniyle fark edilemeyebilir. Bizim olgumuzda da bulgular çocukluk döneminde hafif olduğu için fark edilememişti. Ancak anestezik ajanlarla miyotoni tetiklenir hatta ölümcül komplikasyonlara neden olabilir. İyi bir preoperatif anamnezle ve şüphelenilen hastalarda uygun anestezik ajanların seçimiyle komplikasyonlar önlenebilir.

\section{OLGU SUNUMU}

Olgu I: 54 yaşında kadın hastanın, çocukluk yaşlarında hafif olan, geçirdiği tiroidektomi operasyonu sonrasında belirginleşen yaygın kas sertliği ve güçsüzlük ile Beyin manyetik rezonans (MR) görüntülemesi yapılmış ve normal olarak değerlendirilmişti. Lomber MR görüntülemesinde diskopati bulguları saptanarak medikal tedavi ve fizik tedavi programı verilmişti. Hastanın şikayetlerinde gerileme olmayınca Nöroloji polikliniğine yönlendirilmişti. Kas sertliği istirahat sonrasında ve soğukla artıyor, hareket etmekle ve birkaç adım yürümekle düzeliyordu. Muayenesinde masseter kaslarda belirgin hipertrofi gözlendi (Şekil I). Bulbofasial güçsüzlük ve pitoz yoktu. Gözler sıkıca kapattırıldığında göz kapağını açarken zorlanma saptandı. Kaslarının, özellikle de proksimal kol ve uyluk kaslarının hipertrofik olduğu ve hastanın sıkıca yumruk yapması söylendiğinde gevşemekte güçlük çektiği, birkaç kez tekrarlayınca gevşediği gözlendi (Şekil II, III). Üst ekstremite proksimallerinde hafif güçsüzlüğü vardı. Derin tendon refleksleri normal, taban cildi refleksi bilateral fleksör, duyu muayenesi ve serebeller testleri normaldi. Özgeçmişinde tiroidektomi ve levotiroksin kullanımı dışında özellik yoktu.

Laboratuar çalışmalarında CK, elektrolitler ve tiroid fonksiyon testleri normaldi. Sinir ileti çaIışmalarında median-ulnar-tibial motor, F yanıtları, bileşik kas aksiyon potansiyeli (CMAP) amplitüdleri, distal motor latansları ve iletim hızları normaldi. İğne EMG çalışmasında üst ekstremite ile alt ekstremite proksimal ve distal kaslarda miyotonik deşarjlar saptandı (Şekil IV).

Aile öyküsünde anne-baba akrabalığı olmayan hastanın, erkek kardeşi, kız kardeşi ve üç yeğeninde de benzer şikayetler vardı.

Hastaya Fenitoin sodyum tedavisi başlandı. Tedaviden sonra hastanın şikayetlerinde belirgin iyileşme gözlendi. Hastanın hafif bulantı dışında şikayeti olmadı ve poliklinikten takip ediliyor.

Olgu II: 47 yaşında olan erkek kardeşinin, çocukluk yaşlarında başlayan kaslarda hafif güçsüzlüğü vardı. Yaşıtlarına göre kaslarının iyi gelişmiş görünmesine rağmen, çocukluk yaşlarında belirginleşen merdiven çıkmakta zorlanma ve bazen de oturduğu yerden kalkarken 'blok şeklinde' diye tarif ettiği, kaskatı bir şekilde, adım atmaya çalışırken düşme şikayeti vardı (Şekil V). Hasta şikayetleri nedeniyle daha farklı bölümlere başvurmuş, farklı kas gevşeticiler kullanmış ve fayda görmemiş̧ti. Laboratuar çalışmalarında CK, elektrolitler ve tiroid fonksiyon testleri normaldi. Sinir ileti çalışmalarında median-ulnar-tibial motor, F yanıtları, bileşik kas aksiyon potansiyeli (CMAP) amplitüdleri, distal motor latansları ve iletim hızları normaldi. İğne EMG çalışmasında üst ekstremite ile alt ekstremite proksimal ve distal kaslarda miyotonik deşarjlar saptandı. Fenitoin sodyum tedavisi başlandı ve şikayetlerinde belirgin düzelme görüldü. Hasta poliklinikten takip ediliyor.

Olgu III: 52 yaşında olan kız kardeşinin hafif kas güçsüzlüğü ve kaslarda gevşemede güçlük şikayeti vardı. Şikayetleri çocukluk döneminde başlamış ve ilerlememişti. Tedaviyi kabul etmediği için poliklinikten izleniyor.

Olgu IV: 22 yaşındaki kız yeğeninin benzer yakınmaları vardı. Yakınmaları erken çocukluk döneminde başlamıştı. İğne EMG'sinde üst ekstremite ile alt ekstremite proksimal ve distal kaslarda miyotonik deşarjlar saptandı. Tedaviyi kabul etmediği için poliklinikten izleniyor.

Olgu V: 26 yaşındaki erkek yeğeni, 2 yaşında yürümeye başlamış ve çocukluğundan beri kol 
ve bacaklarında güçsüzlük vardı. Merdiven çıkarken ve oturduğu yerden kalkmakta zorlanma tarifleyen hastanın şikayetlerinde ilerleme olmamıştı. Anne-baba akrabalığı (amca çocukları) olan hastanın, kız kardeşinde de benzer şikayetler vardı (Olgu VI). Muayenesinde üst ve alt ekstremitelerde 4/5 motor defisiti olan hastanın kaslarında yaygın hipertrofi saptandı. Hastanın sıkıca yumruk yapması söylendiğinde gevşemekte ve sandalyeden kalkmakta zorluk vardı. Derin tendon refleksleri hipoaktif, taban cildi refleksi bilateral fleksör, duyu ve serebeller testleri normaldi. Laboratuvar değerlerinde CK düzeyi: 450 (0-200) ile yüksek, elektrolitleri ve tiroid fonksiyon testleri ise normaldi. Beyin MR görüntülemesi normaldi ve ekokardiyografisinde septum bazalinde geçirilmiş ventriküler septal defekt operasyonuna bağlı semiparadoks saptandı. Sinir ileti çalışmalarında median, ulnar, tibial motor, F yanıtları, CMAP amplitüdleri, distal motor latansları ve iletim hızları normaldi. Median, ulnar ve sural sinir duyu çalışmaları normaldi. İğne EMG çalışmasında üst ekstremite ile alt ekstremite proksimal ve distal kaslarda miyotonik deşarjlar saptandı. Kardiyak problemleri nedeniyle karbamazepin tedavisi başlandı.

\section{TARTIŞMA}

Konjenital miyotoni; ilerleyici olmayan, ağrısız miyotoni ve kas hipertrofisi ile karakterizedir. Prevalansı tüm dünyada yaklaşık 1/100000'dir (1). Hastaların hareketleri yavaşlatılmış filmi andırır şekildedir (2). Karakteristik olarak hastalar yaygın kas hipertrofisine bağlı 'herkül' benzeri görünüme sahip olurlar (3). Muayeneye gelen tüm olgularımızın fizik muayenelerinde masseter, alt ekstremite ve üst ekstremite kaslarında belirgin hipertrofi saptandı.

\section{Thomsen hastalığı insidansı yaklaşık} 2-7,3/100.000'dir (4). Thomsen hastalığında, belirtiler erken çocukluk döneminde başlar, miyotoni yaygın olmasına rağmen, üst ekstremitelerde daha şiddetli olma eğilimindedir ve belirgin kas hipertrofisi eşlik eder. Belirtiler daha çok üst ekstremitede ve yüz kaslarında belirgin kas hipertrofisi, geçici kas katılığı ve dinlenme sonrası kasın tekrar gevşemesi ile karakterizedir. Prognozu yaşam süresini etkilemeksizin iyidir. Çünkü Thomsen hastalığı olan çocuklar yaşıtlarına göre kasları daha hipertrofik olduğu için sportif faaliyetlere dahil edilme oranları da diğer ya- şıtlarına göre yüksektir (5). Bizim olgumuzun belirtilerinin çocukluk yaşlarında başlaması, belirtilerinin hafif olması ve daha çok üst ekstremitelerde belirgin güçsüzlüğünün ve yaygın kas hipertrofisinin olması ile Thomsen varyantı olduğunu düşündük.

Becker varyantı belirtileri ise yaşamın ikinci dekatında bazen de üçüncü ve dördüncü dekatında ortaya çıkar. Erken yaşlarda belirtiler sinsidir, sadece elektrofizyolojik testlerle tanı konur. Becker varyantında belirtiler Thomsen varyantına göre daha şiddetlidir ve daha çok alt ekstremiteleri tutma eğilimindedir. Bazen alt ekstremite kaslarında yavaş ilerleyen güçsüzlük ve kas hipertrofisi ile özellikle el ve kol kaslarını içeren proksimal güçsüzlük epizodları görülür (5). Olgu I, II, III, IV, VI'da belirtiler hafif ancak olgu V'te diğerlerinden farklı olarak belirtiler daha şiddetliydi.

Normal şartlarda kas lifi membran potansiyeli hücre içine klor girişi ile deporalizasyon sonrası tekrar repolarize olur. Thomsen ve Becker tip miyotonide ise mutasyona uğramış klorid kanallarının azalmış klor iletkenliği kas liflerinin aşırı uyarılmasına ve anormal aksiyon potansiyeli patlamalarına neden olur Yapılan birçok genetik çalışmada Konjenital miyotoniden sorumlu olan gen CLCN1 geni olarak saptanmıştır. Hangi genin ya da kaç tanesinin hastalığa neden olduğu tam olarak bilinmese de 2007 yılından bu yana yaklaşık 80 tane mutasyon tanımlanmıştır. Bir ailede aynı mutasyon tipi görülse de aile bireylerinin hastalık fenotipi ve progresyonu farklı olabilir bu da multigenetik ve / veya bu miyotonik fenotiplerinin epigenetik modülasyonuna işaret etmektedir (5). Bizim olgularımızdan olgu V'in fenotip ve progresyonu diğerlerine göre daha kötüydü. Otozomal dominant ve otozomal resesif formları tanımlanmıştır ve her iki formda da aynı mutasyon rapor edilmiştir. OD geçişli Thomsen formunda klinik fenotip, OR geçişli Becker formuna göre daha hafiftir (6). Bazı hastalarda klinik özellikler ile OD ve OR formları birbirinden ayırmak zordur, OR heterozigot semptomatik hastalar ile OD hastaları klinik özelikleri ile birbirinden ayırmak da zor olabilir. Bizim hastalarımızda teknik nedenlerden dolayı genetik tanıları yapılamadı. Ancak olgu V'in kliniğinin diğer tanı koyulan aile bireylerinden daha farklı olması hastalık geninin, multigene- 
tik ve / veya myotonik fenotiplerinin epigenetik modülasyonu olabileceğini düşündürdü.

Konjenital miyotoni, ayırıc tanısında yer alan Miyotonik distrofide progresif seyreden distal kaslar ile yüz kaslarında atrofi, ekstramuskuler tutulum ve güçsüzlük olur. Myotoniyi tetikleyen ve azaltan faktör yoktur. Olgularımızın hiçbirinde kaslarda atrofi yoktu. Miyotonileri istirahat ile artıyor, egzersizle azalıyordu ve progresyon göstermiyordu. Paramiyotoni konjenitada ise kaslarda sertlik ile birlikte devamlı aktivite, periyodik ve progresif seyreden güçsüzlük vardır.

Miyotoninin altta yatan mekanizması, kas kontraksiyonunu izleyen tekrarlayıcı membran aktivasyonudur. Konjenital miyotonide kas membran direnci artmıştır. Miyotoni tedavisinde membran repolarizasyon hızını etkileyen ve membran stabilitesini artıran ilaçların kullanımı temel alınmıştır. Becker hastalarının aksine Thomsen hastalarının çoğunda medikal tedaviye ihtiyaç vardır (7).

Konjenital miyotoni tedavisi yaşam tarzı değişiklikleri başlar. Relaksasyon teknikleri faydalıdır, stres miyotoniyi artırabilir. Uzun süreli istirahat ve aynı pozisyonda kalmaktan, uzun süreli istirahat sonrası yaralanma ve kas gerginliği oluşmaması için ani hareketlerden kaçınmak gerekir. Farmakolojik tedavi ciddi miyotonisi olan hastalarda gereklidir. İskelet kas membranının aşırı uyarılabilirliği ile karakterize olan hastalığın tedavisi membran stabilizasyonu esasına dayanır (3). Hangi tedavinin seçileceği potansiyel yan etkilere göre belirlenir. İlk seçilecek tedavi sınıf 1 b antiaritmik ajan olan mexiletin olup, soyum kanalları üzerine etkilidir. Kardiyak aritmi, kardiyomyopati ve koroner arter hastalığı olanlarda kontrendikedir. Diğer seçenek tedavi de lidokain derivesi olan, sodyum kanalları üzerine etkili tocainidedir. Miyotoniyi kontrol etmede mexiletin kadar etkili bulunmuştur ancak kemik iliği üzerine baskılayıcı etkilerinden dolayı tocaidin 2. seçenek tedavi olmuştur (8). Bir vaka sunumunda karbamazepin tedavisi etkili bulunmuştur ve bu etkisi post tetanik potansiyelleri azaltarak membran stabilizasyonu yapması ile açıklanmıştır (3). Diğer bir tedavi seçeneği olan, voltaj bağımlı sodyum kanal ve kalsiyum kanal modülasyonu yapan fenitoinin; çalışmalarda karbamazepin kadar etkili ama yüksek dozlarda etkisinin azaldığı bulunmuştur. Olgu I ve olgu II' ye fenitoin tedavisi başlandı. Hastalar tedavi sonrasında şikayetlerinde azalma tarifledi. Olgu 5'e, kardiyak hastalık öyküsünde dolayı karbamazepin tedavisi başlandı. Olgu V'te kardiyak aritminin olmaması, şikayetlerinin progresyon göstermemesi, katarakt, testiküler atrofi ve endokrin anormalliklerin olmaması, EMG de Konjenital miyotoniye spesifik üst ekstremite, alt ekstremite proksimal ve distal kaslarda miyotonik deşarjlar saptanması ile Miyotonik distrofi tanısından uzaklaşıldı.

Lityumun da sodyum transportunda değişiklik yaparak ve adrenerjik reseptörleri artırarak myotoniyi iyileştirildiği düşünülmektedir (8).

Konjenital miyotoni hastalarında cerrahi öncesi iyi bir anamnez ve muayene ile alınacak önlemler ile cerrahi sonrası gelişebilecek komplikasyonlar önemli ölçüde engellenebilir. Hastalar anestezi ajanlarının riskleri ve depolarizan kas gevşeticilerin kullanımı açısından uyarılmalıdır. Konjenital miyotoni hastalarında cerrahi sırasında kullanılan depolarizan kas gevşeticiler sonrasında yaygın kas spazmı şeklinde ciddi miyotonik yanıt gelişme riski yüksektir. Bu miyotonik yanıt gebelerde ve hipotiroidizmi olanlarda daha ciddidir (5). Olgu l'e de daha önce silik şikayetlerinin olması ama geçirdiği tiroidektomi operasyonu sonrası şikayetlerinin belirginleşmesi ile tanı konuldu.

Malign hipertermi de en ciddi ve ölümcül komplikasyondur (1). Malign hipertermi (MH); kasın farmakogenetik metabolik bir hastalığıdır. Kalsiyumu regüle eden proteinlerin mutasyonu ile ilgilidir. Sarkoplazmik retikulumdan, miyoplazmik kalsiyumun anormal yüksek saıınımı vardır. Asidoz, hipertermi, kas rijiditesi, rabdomiyoliz ile karakterize klinik tablo ile seyreder. Dantrolen, orijinali antibiyotik olarak geliştirilmiş bir hidantoin türevidir. Selektif olarak iskelet kasında kalsiyum kanallarını bloke eder. Sarkoplazmik kalsiyum serbestleşmesini antagonize ederek yüksek kalsiyum konsantrasyonunu düşürür. Böylece $\mathrm{MH}$ epizodunu geri çevirdiği bildirilmiştir (8). MH riski olan olgularda 
ise profilaksi amacıyla kullanılması yanında; $\mathrm{MH}$ tedavisi, nöroleptik malign sendrom, spastisite ve ekstazi intoksikasyonunda da kullanılmaktadır. Genel anestezi uygulamasında en sık olarak Halothane ile $\mathrm{MH}^{\prime}$ ye rastlanmış olup daha sonra kullanıma giren sevofluran güvenli olarak bildirilmiştir. Sevofoluran kullanımının artması ile birlikte sevoflurana bağlı MH vakaları da bildirilmeye başlamıştır.

Suksametonyum gibi kas gevşeticiler Ach-reseptörlerine bağlanarak sodyum ve kalsiyum akışına neden olurlar. Suksametonyum kısa etki sürelidir ve plazma pseudokolinesterazları tarafından metabolize edilir. Eğer nöromusküler aralıkta pseudokolinesteraz az ya da hiç yoksa nöromuskuler blok indüklenir ve suksametonyum difüzyon ile nöromuskuler aralıktan uzaklaştırılır. Bu da kasta uzamış depolarizasyona neden olur (1). Suksametonyum, süksinilkolin ve propofol myotoniye neden olur. Anestezi sırasında non-depolarizan kas gevşetici ajanlar tercih edilmelidir. Anestezik ajanlar yanında postoperatif dönemde görülen ağrı ve stress de malign hipertermiyi tetikleyebilir (9). Bu nedenle etkin postoperatif analjezi sağlanması önemlidir. Hastalar cerrahi sırasında da sıcak tutulmalıdır (10). Konjenital miyotoni seyri beningdir ancak cerrahi sırasında ölümcül komplikasyonlar açısından dikkat edilmesi gerekir. Anestezi indüksiyonu sırasında masseter kaslarda rijidite gelişmesi ve ventilatörden geç ayrılma durumunda miyotonik hastalıklar akla gelmelidir.

Sonuç olarak hikaye, muayene bulguları ve laboratuvar çalışmaları ile uyumlu olarak hastamıza Konjenital miyotoni tanısı konuldu. Konjenital miyotoni tanısı klinik prezantasyon ve EMG bulguları ile koyulur ve genetik tanı ile kesinleştirilir. Olgu I ve ardından Konjenital miyotoni tanısı alan tüm diğer aile bireyleri takibe alındı. Bu yazıda; Konjenital miyotoninin; nadir görülen, non-progresif, jeneralize kas hipertrofisi ve miyotoni ile seyreden, tanı koyulduğunda aile taraması yapılması ve cerrahi öncesi anestezistlerin bilgilendirilmesi gereken bir hastalık olduğunu vurguladık.

\section{KAYNAKLAR}

1. Farbu E, Søfteland E, Bindoff LA . Anaesthetic complications associated with myotonia congenita: case

study and comparison with other myotonic disorder. Acta Anaesthesiol Scand 2003;47: 630-4.

2. Brett EM, Lake BD. Neuromuscular disorders: Primary muscle disease and anterior horn cell disorders. In: Brett EM, Livingston C, eds. Pediatric Neurology, 3rd edn. New York: Mosby, 1997: 70-7.

3. Savitha M R, Krishnamurthy B, Abbas Hyderi, et al. Myotonia congenita--a successful response to carbamazepine. Ind J Pediatr 2006; 73(5):431-3

4. Michael J, Lyons MD, Reyna Duron MD et al. Novel CLCN1 Mutation in carbamazepine-responsive myotonia congenita. Pediatric Neurology. 2010; 42(5):365-368

5. Parness J, Bandschapp O, Girard T. The Myotonias and Susceptibility to Malignant Hyperthermia. Anesth Analg 2009;109(4):1054 -64.

6. de Diego C, Gámez J, Plassart-Schiess E, et al. Novel mutations in the muscle chloride channel CLCN1 gene causing myotonia congenita in Spanish families. J Neurol 1999 ;246(9):825-9.

7. Heatwole CR. Moxley RT. The nondystrophic myotonias. Neurotherapeutics. 2007;4(2):238-51.

8. Gronert GA, Antognini JF, Pessah IN: Malignant Hyperthermia in: Miller RD Anesthesia 5th edition. NewYork Churchill Livingstone; 2000;1033.

9. Cohen IT, Kaplan R: Repeat episodes of severe muscle rigidity in a child receiving sevoflurane. Paediatr Anaesth 2006;16(10):1077-1079.

10. Conravey A, Santana-Gould L. Myotonia Congenita and Myotonic Dystrophy: Surveillance and Management. Current Treatment Options in Neurology 2010; 12(1):1628. 